\title{
Anaerobic Digestion of Liquid Waste from an Attiéké Factory: From the Experimental Scale to the Semi-Industrial Scale
}

\author{
Nazo Edith Kpata-Konan ${ }^{1}$, Kouamé Martin Kouamé2, Yao Francis Kouamé ${ }^{2}$, \\ Sylvestre Ahou Yaovi ${ }^{3,4}$, Koffi Felix Konan'2, Theophile Gnagne ${ }^{5}$ \\ ${ }^{1}$ Department of Agroforestry, University Jean Lorougnon Guédé, Daloa, Côte d'Ivoire \\ ${ }^{2}$ Department of Environment, University Jean Lorougnon Guédé, Daloa, Côte d’Ivoire \\ ${ }^{3}$ IMT-Atlantique, GEPEA UMR CNRS 6144, Nantes, France \\ ${ }^{4}$ Laboratory of Biology and Molecular Typing in Microbiology, LBTMM, UAC, Abomey-Calavi, Benin \\ ${ }^{5}$ Department of Science and Environmental Management, Université Nangui Abrogoua, Abidjan, Côte d'Ivoire \\ Email: *kpataedith@gmail.com
}

How to cite this paper: Kpata-Konan, N.E., Kouamé, K.M., Kouamé, Y.F., Yaovi, S.A., Konan, K.F. and Gnagne, T. (2020) Anaerobic Digestion of Liquid Waste from an Attiéké Factory: From the Experimental Scale to the Semi-Industrial Scale. Journal of Environmental Protection, 11, 531-539. https://doi.org/10.4236/jep.2020.117031

Received: April 29, 2020

Accepted: July 13, 2020

Published: July 16, 2020

Copyright (c) 2020 by author(s) and Scientific Research Publishing Inc. This work is licensed under the Creative Commons Attribution International License (CC BY 4.0).

http://creativecommons.org/licenses/by/4.0/

\begin{abstract}
This study focused on the transfer of experimental results of anaerobic digestion of liquid waste from an attiéké (steamed cassava semolina) factory to a 6 $\mathrm{m}^{3}$ pilot digester. The experimental digester and the pilot were powered as follows: $\mathrm{Lw}+\mathrm{U}+\mathrm{C}$ (liquid waste + urine + cow dung). To the results, the experimental digester mesophilic with a progressive elimination of COD. Also, the nitrogen concentrations in the experimental reactor had little removal with alkaline $\mathrm{pH}$. As for the biogas product in this digester, a volume of 3.6 $\mathrm{m}^{3}$ was obtained with a positive flammability test. The transition from the laboratory scale to the semi-industrial scale retains the results of purification and fuel biogas production of the experimental digester.
\end{abstract}

\section{Keywords}

Anaerobic Digestion, Cassava Liquid Waste, Biogas

\section{Introduction}

Cassava (Manihot esculenta) is the third food product in the tropics after rice and maize (FAO 2008) [1]. Annual production in Côte d'Ivoire, estimated at $2,450,000$ tones, ranks second among food crops after yam (FAO, 2010, 2013) [2]. In addition, the ease and control of fresh cassava processing technologies makes it possible to obtain various products such as: gari, tapioca, placali, kokodé, attoupkou, attiéké, etc. (Akoroda, 2007 [3]; Kpata-Konan et al., 2013 [4]). 
Very popular in Côte d'Ivoire where it has become a national dish, attiéké (steamed cassava semolina) is the main form of food use for cassava. Indeed, originally from the south, this dish is now produced and consumed throughout Côte d'Ivoire and by all socio-economic groups. Thus, this cassava-based food is now widely adopted across Africa, even the world.

However, does the manufacturing process of attiéké generate toxic liquid waste (Goualo et al., 2007 [4]; Kpata-Konan et al., 2013 [5]; Kpata-Konan et al., 2016 [6]; Kpata-Konan et al., 2018 [7]; Kpata-Konan et al., 2019 [8]), with a very high pollutant load (Ubalua, 2007 [9]; Kpata-Konan et al., 2016 [6]), which is released into the environment without prior treatment. This waste is an important source of pollution for the receiving environment. Indeed, these wastes degrade the living environment, generate olfactory nuisances, promote the spread of pathogens and cause risks to human and animal health (Marache, 2001) [10]. Also, cooking attiéké is done in a traditional way with a large consumption of energy whose main source is firewood or charcoal.

In Côte d'Ivoire, waste treatment trials using anaerobic digestion have been carried out on agricultural waste (Anonyme, 1981) [11], household waste (N'goran, 2006) [12] and cow dung (Kouamé, 2006) [13]. Thus, in order to substitute the current energy source for the production of attiéké by bioenergy, an attempt to produce biogas by digesting liquid waste from the production of attiéké was made in Azito-Village in the Commune of Yopougon (Mahan, 2004 [14]; Kpata, 2005 [15]). But the biogas produced was not combustible. Indeed, liquid cassava waste is biorecalcitrant with an acidic $\mathrm{pH}(\mathrm{pH}<3)$ and a nitrogen deficiency $(0.6$ - $0.8 \mathrm{~g} / \mathrm{L}$ ). To contribute to improving the purification performance of the anaerobic digester in the purification of liquid cassava waste from the attiéké manufacturing process, studies have been initiated on the co-digestion of this waste with human urine and cow dung. This anaerobic digestion can reduce the organic pollutant load by half. In addition, the residues (or digestate) obtained after anaerobic digestion are stable, deodorized, mostly free of pathogens and rich in nitrogen compounds (ammoniacal nitrogen, total nitrogen) (Kalloum et al., 2011 [16]; Kpata-Konan et al., 2016 [6]). They can therefore be valued for the amendment of agricultural soils.

This work aims to transfer the experimental results (experimental scale with a digester of around $200 \mathrm{~L}$ ) of anaerobic digestion optimization of liquid waste from an attiéké factory to a $6 \mathrm{~m}^{3}$ (semi-industrial) pilot digester.

\section{Material and Methods}

\subsection{Material}

\subsubsection{Co-Substrates}

The substrates used consist of:

- $2.3 \mathrm{~m}^{3}$ of liquid waste from the pressing of cassava paste and washing of chips;

- $1.7 \mathrm{~m}^{3}$ of human urine collected in the village of Azito;

- $323 \mathrm{Kg}$ of cow dung collected at the Azito slaughterhouse. 


\subsubsection{Reactors Design and Experimental Conditions}

An experimental anaerobic reactor has been used (Figure 1(a) and Figure 1(b)). This reactor consisted of two metal drums of $100 \mathrm{~L}$ and $186 \mathrm{~L}$, each open on one of the bases. The largest barrel contained digestion substrate and the smallest barrel was used as gasometer to store the produced gas. The experimental reactor used was powered as follows: Cassava liquid waste + human urine + cow dung $(\mathrm{Lw}+\mathrm{U}+\mathrm{C})$.

For pilot scale, anaerobic digestion was carried out in a $6 \mathrm{~m}^{3}$ capacity bioreactor, closed hermetically (Figure 1(c) and Figure 1(d)). This digester has three parts. The upper part is occupied by the biogas produced. With a volume of 2 $\mathrm{m}^{3}$, the gas holder is equipped with a check valve, a safety relief valve and a manometer. The central part is occupied by the biodigestion cosubstrate (cassava liquid waste, human urine and cow dung). The reaction mixture has a volume of $4 \mathrm{~m}^{3}$. This part of the semi-industrial biodigester comprises a digester mixer powered by a gear motor FIMET, pipe supply, a discharge pipe on which is fixed a valve flap. The mixer is used to homogenize the medium so as to avoid sedimentation. The feed pipe is used for supplying the digester from a motor pump SDMO ST $2.36 \mathrm{H}$. As to the discharge pipe, situated at the bottom of the digester, it serves to drain the reactor.

\subsection{Methods}

Temperature, pH, Chemical Oxygen Demand (COD) and Total Nitrogen (estimated by Kjeldahl the method ((TKN)) were determined according to the standard methods (Table 1). Temperature, $\mathrm{pH}, \mathrm{COD}$ and TKN were determined

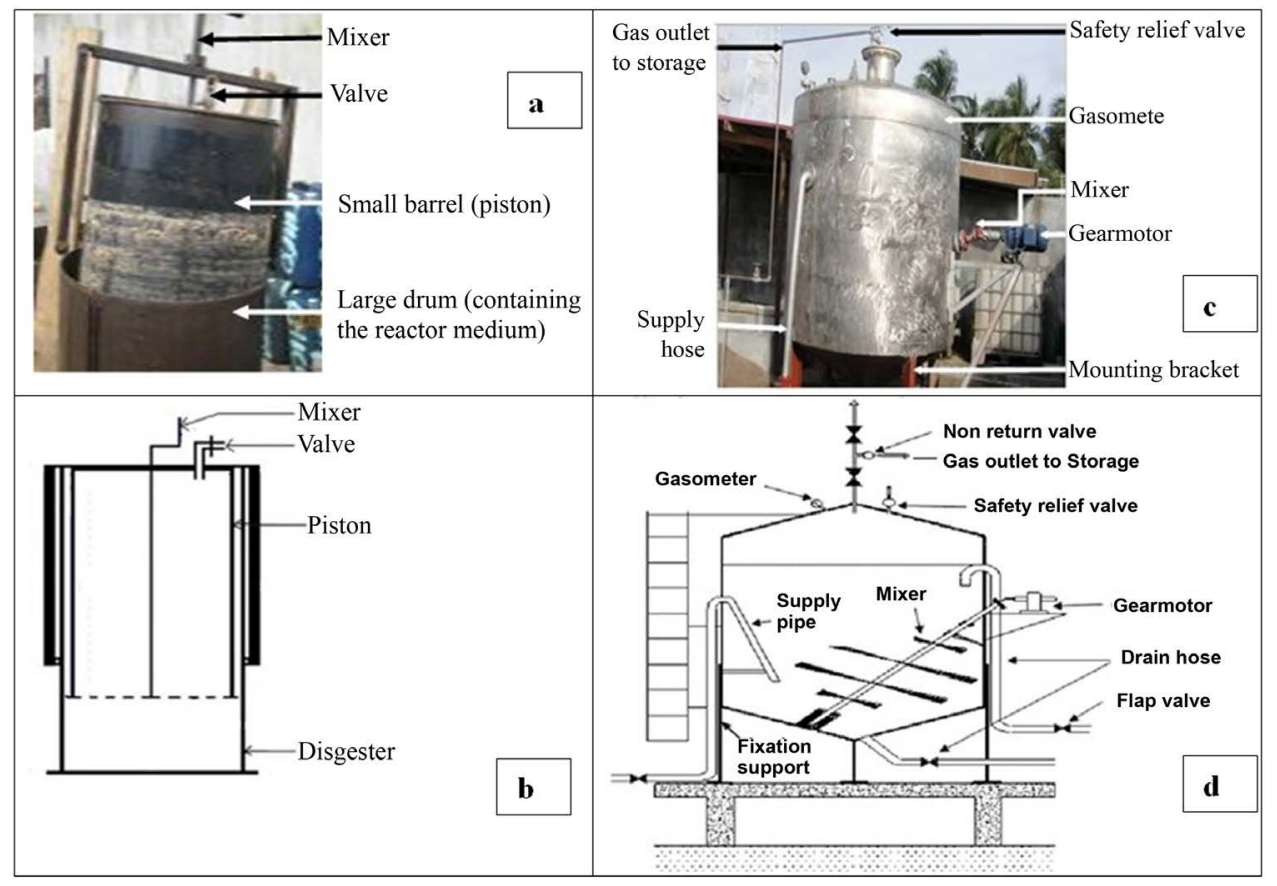

Figure 1. (a) and (b) $186 \mathrm{~L}$ experimental digester, (c) and (d) $6 \mathrm{~m}^{3}$ pilot digesters. Schemas (b) and (d) are respectively from Kpata-Konan et al. (2013) [5] and Kpata-Konan et al. (2015) [17]. 
Table 1. Synthesis of methods for the analysis of physico-chemical parameters (AFNOR, 1994 [18]; Rodier, 1996 [19]; CEAEQ, 1999 [20].

\begin{tabular}{|c|c|c|}
\hline Measured parameters & Analytical Methods & Comments on methods \\
\hline $\mathrm{pH}$ and temperature & $\begin{array}{l}\text { Electrochemical glass } \\
\text { electrode (NF T 90-008) }\end{array}$ & $\begin{array}{l}\text { In situ measurement using HANNA brand } \\
\mathrm{pH} \text {-meter }\end{array}$ \\
\hline $\begin{array}{l}\text { Total Kjeldahl Nitrogen } \\
(\mathrm{TKN})\end{array}$ & $\begin{array}{l}\text { Method after selenium } \\
\text { mineralization (NF T 90-010) }\end{array}$ & $\begin{array}{l}\text { Digestion of } 50 \mathrm{ml} \text { of sample and } \\
\text { determination by titrimetry after distillation. }\end{array}$ \\
\hline $\begin{array}{l}\text { Chemical Oxygen } \\
\text { Demand (COD) }\end{array}$ & $\begin{array}{l}\text { Potassium dichromate } \\
\text { oxidizability method } \\
\text { (NF T 90-101) }\end{array}$ & $\begin{array}{l}\text { Oxidation by excess dichromate in an acidic } \\
\text { medium followed by a dosage of the excess } \\
\text { dichromate by the mixed iron and } \\
\text { ammonium sulfate. }\end{array}$ \\
\hline
\end{tabular}

twice per week. In this study. Carbon and nitrogen compounds were respectively determined as COD and TKN. The $\mathrm{C} / \mathrm{N}$ ratio was estimated from the COD/TKN ratio.

Experimental digester: Volume $(V)$ of biogas produced was measured daily using this formula:

$$
V=H \pi R^{2}
$$

with $H=$ height of rising of the gasometer (small barrel); $R=$ Radius of the gasometer (small barrel).

Pilot: Volume $(V$ ) of biogas produced was measured daily using this formula:

$$
V=\frac{P_{i}}{P_{\text {atm }}} \times e^{1 /(\gamma \times V 1)}
$$

with $P_{i}=$ initial pressure (bar); $P_{\text {atm }}=$ Atmospheric pressure (bar); $\gamma=1.42(\mathrm{Ga}-$ ma for natural gas); $V 1=$ Volume of gas holder $\left(\mathrm{m}^{3}\right)$.

The composition of the produced biogas was determined by gas chromatography. The energy value was obtained using the formula described by Ricard et al. (2010) [21], of the order of: $9.65 \mathrm{kWh} / \mathrm{m}^{3}$ under standardized conditions. Depending on its methane content, the energy value of the biogas produced is obtained as follows:

$$
\mathrm{LCV}=9.65 M
$$

with: LCV: lower calorific value, expressed in $\mathrm{kwh} / \mathrm{m}^{3} ; M$ : percentage of methane in the biogas produced.

\section{Results and Discussion}

\subsection{Characteristics of Substrate at the Inlet of Digesters}

The COD of the human urine used is $12.64 \mathrm{~g} / \mathrm{L}$ for an estimated TKN concentration of $2.64 \mathrm{~g} / \mathrm{L}$ with a basic $\mathrm{pH}$ of 8.99 (Table 2). The liquid waste from the digesters was buffered before feeding. For the experimental digester, the recorded values of COD, TKN and $\mathrm{pH}$ are respectively $18.80 \mathrm{~g} / \mathrm{L}, 3.75 \mathrm{~g} / \mathrm{L}$ and 7.00. In the pilot digester, the COD, TKN and $\mathrm{pH}$ values observed are $27.46 \mathrm{~g} / \mathrm{L}, 3.87 \mathrm{~g} / \mathrm{L}$ and 7.02 respectively (Table 2 ). The COD/TKN ratio were 4.97 for the experimental digester and 7.08 for the pilot digester. 
Table 2. Substrate parameters at the inlet of the digesters.

\begin{tabular}{cccc}
\hline Parameters & Human urine & Expérimental Digester & Pilot \\
\hline $\mathrm{COD}(\mathrm{g} / \mathrm{L})$ & 12.64 & 18.80 & 27.46 \\
$\mathrm{TKN}(\mathrm{g} / \mathrm{L})$ & 2.64 & 3.78 & 3.87 \\
$\mathrm{COD} / \mathrm{TKN}$ & 0.47 & 4.97 & 7.08 \\
$\mathrm{pH}$ & 8.99 & 7.00 & 7.02 \\
\hline
\end{tabular}

\subsection{Physico-Chemical Parameters of the Mixture at the Outlet of the Digesters}

The experimental digester and pilot showed pollutant load reductions ranging from $18.78 \mathrm{~g} / \mathrm{L}$ to $0.29 \mathrm{~g} / \mathrm{L}$ and $27.46 \mathrm{~g} / \mathrm{L}$ to $5.01 \mathrm{~g} / \mathrm{L}$ respectively (Table 3 ). The corresponding purification efficiencies are $98.43 \%$ for the experimental digester and $81.75 \%$ for the pilot.

The amount of nitrogen observed in all digesters decreased slightly throughout the experiment. The observed TKN concentrations ranged from $3.78 \mathrm{~g} / \mathrm{L}$ to $2.49 \mathrm{~g} / \mathrm{L}$ for the experimental digester and from $3.87 \mathrm{~g} / \mathrm{L}$ to $2.08 \mathrm{~g} / \mathrm{L}$ for the pilot. The corresponding purifying yields are $34.07 \%$ for the experimental digester and $46.18 \%$ for the pilot.

The COD/TKN ratio varied from 4.97 to 0.11 in the experimental reactor and from 0.86 to 0.50 in the pilot (Table 3 ).

The average temperatures recorded in the experimental digester and the pilot are $28.03^{\circ} \mathrm{C}$ and $29.0^{\circ} \mathrm{C}$ respectively. In the digesters, the average $\mathrm{pH}$ is 7.45 for the experimental and 7.87 for the pilot.

\subsection{Biogas Produced at the Different Digesters}

The cumulative biogas production recorded at the experimental reactor after 114 days of operation is $3.60 \mathrm{~m}^{3}$. That of the pilot was $359.18 \mathrm{~m}^{3}$ after 192 days of operation (Figure 2). At the flammability test, it is positive in the experimental digester and the pilot after respectively from the 4th day until the end of the experiment and after 50 days of operation.

\subsection{Discussion}

The analysis results show a progressive elimination of the pollutant load (COD) of liquid waste. This indicates that the digesters are working well overall. According to Doré (1989) [22], these reductions of the polluting load could be explained by the potential consumption of organic matter by the purifying microflora during its natural evolution in these digesters.

For nitrogen pollution, the concentrations observed in all digesters decreased slightly throughout the experiment. This small decrease in nitrogen could be explained by the low volatilization of ammonia nitrogen observed in anaerobic digestion (Maiga et al., 2008) [23]. Indeed, Barana (2000) [24] reported that anaerobic digestion processes conserve nitrogen. 
Table 3. Variation of physico-chemical parameters at the outlet of experimental digesters.

\begin{tabular}{ccc}
\hline Parameters & Experimental digester & Pilot \\
\hline COD $(\mathrm{g} / \mathrm{L})$ & $18.78-0.29$ & $27.46-5.01$ \\
Carbonaceous purifying efficiency (\%) & 98.43 & 81.75 \\
$\mathrm{TKN}(\mathrm{g} / \mathrm{L})$ & $3.78-2.49$ & $3.87-2.08$ \\
Nitrogenous purification efficiency (\%) & 34.07 & 46.18 \\
$\mathrm{COD} / \mathrm{TKN}$ & $4.97-0.11$ & $0.86-0.50$ \\
Average $\mathrm{T}^{\circ} \mathrm{C}$ & 28.03 & 29.0 \\
Average $\mathrm{pH}$ & 7.45 & 7.87 \\
\hline
\end{tabular}

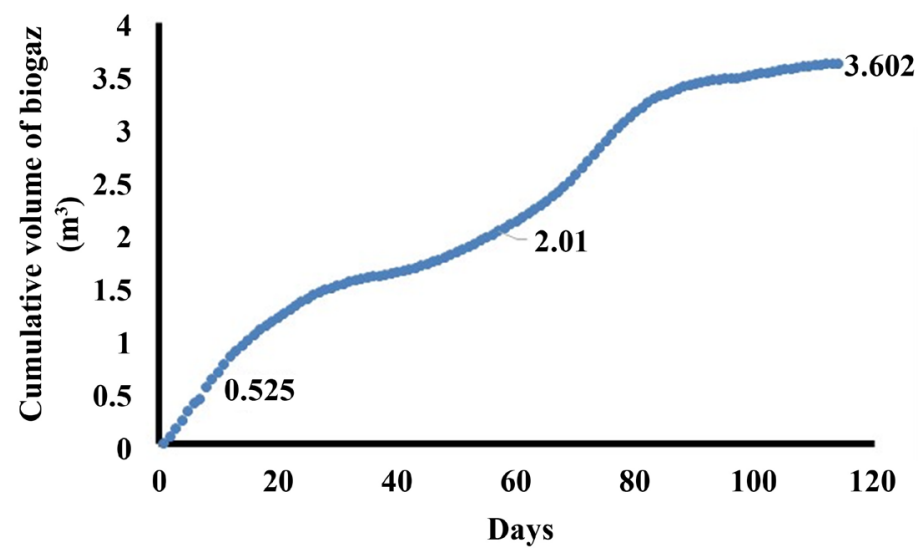

(a)

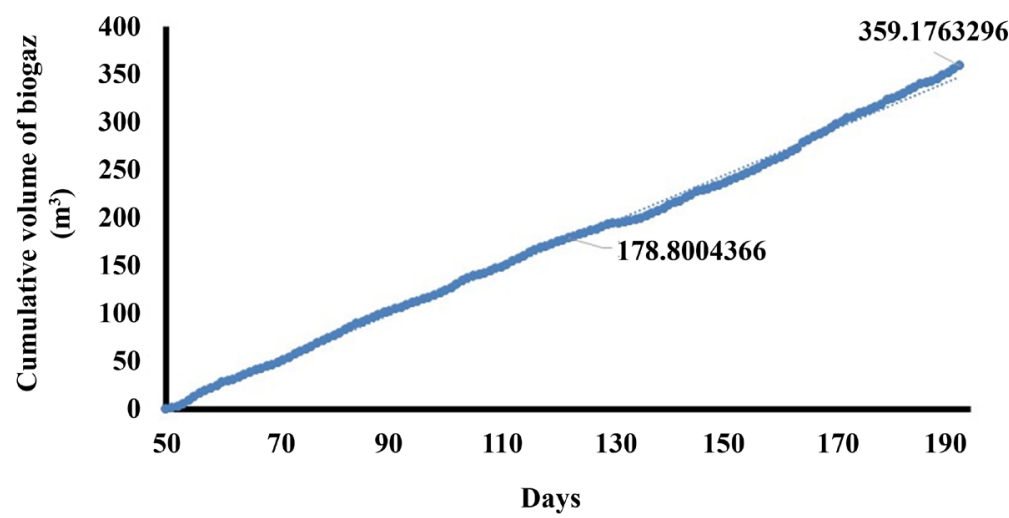

(b)

Figure 2. Cumulated volume of biogas produced during the monitoring time of the experimental (a) and pilot (b) digesters.

In this study, the treatment of cassava liquid waste with human urine reduced the COD/TKN ratio to below 50 as recommended by Liu et al. (2008) [25] for anaerobic treatment.

Concerning temperature, all digesters operated in the mesophilic fermentation range $\left(24^{\circ} \mathrm{C}\right.$ and $\left.35^{\circ} \mathrm{C}\right)$. This temperature range is favored by the country's tropical climate characterized by strong sunshine and average annual temperatures above $26^{\circ} \mathrm{C}$ (Kouamé et al., 2010) [26]. According to De La Farge (1995) 
[27], mesophilic systems are the most common and best controlled.

The digesters worked with alkaline $\mathrm{pH}$ values. This alkalinity could be explained by the contribution of human urine, which is of a basic nature (Kpata, 2005) [15], to the acid cassava effluent (Ubalua, 2007) [9].

Biogas production and flammability testing are important for controlling and monitoring the anaerobic digestion process. A positive flammability test indicates that the digester is working properly. In the pilot digester, the flammability test was recorded after 50 days of operation, unlike the experimental digester which was observed on the 4 th day of operation. This relatively long time before gas combustion could be justified by the lack of cow dung introduced into the reactor, which did not favour the rapid development of microorganisms. Indeed, the work of Kalloum et al. (2007) [28] on the anaerobic digestion of household waste and Igoud et al. (2002) [29] on the anaerobic digestion of bovine waste produced biogas after 25 and 10 days of operation respectively.

\section{Conclusions}

This work focused on the transfer of the results of anaerobic digestion of liquid waste of the attiéké (steamed cassava semolina) factories from the experimental scale to a pilot. This study was conducted over 114 days for the experimental digester and 192 days for the pilot. The transition from laboratory to semi-industrial scale maintains the results of purification and biogas production despite the production of fuel biogas after 50 days of operation in the pilot. However, it is becoming economically obvious that the production of biogas from the liquid waste from the attiéké (steamed cassava semolina) factories will be an important source of income, which could effectively reduce the use of firewood for cooking the attiéké.

In order to consolidate the results of liquid cassava waste treatment by anaerobic digestion with human urine as co-substrate and to facilitate the popularization of this technology, it would be interesting to accompany it with an engineering effort to automate the feeding of raw wastewater to the biodigester and the evacuation of the digestate.

\section{Conflicts of Interest}

The authors declare no conflicts of interest regarding the publication of this paper.

\section{References}

[1] FAO (2008) La situation mondiale de l'alimentation et de l'agriculture. Food and Agriculture Organization of the United Nations, Rome, 153 p.

[2] FAO (2010-2013) La stratégie de la FAO pour la fourniture d'avis scientifique en matière de sécurité sanitaire des Aliments. Food and Agriculture Organization of the United Nations, Rome, $37 \mathrm{p}$.

[3] Akoroda, M.O. (2007) Consommation et organisation du marché de manioc en Afrique de l'Ouest. Actes de 1 Atelier Potentialités à la transformation du manioc en 
Afrique de l Ouest, Abidjan, 4-7 juin 2007, 24-47.

[4] Kpata-Konan, N.E., Gnagne, T., Konan, K.F., Bony, K.Y., Kouamé, K.M., Kouamé, Y.F. and Tano, K. (2013) Improving Anaerobic Biodigestion of Manioc Wastewater with Human Urine as Co-Substrate. International Journal of Innovation and Applied Studies, 2, 335-343.

[5] Goualo, B.C., Djedji, E.B.C. and Kamenan, A. (2007) Etude des caractéristiques chimiques de nouvelles variétés de manioc (Manihot esculenta Crantz). Actes de 1 Atelier "Potentialités à la transformation du manioc en Afrique de POuest", Abidjan, 4-7 juin 2007, 204-207.

[6] Kpata-Konan, N.E., Konan, K.F., Kouamé, Y.F., Gnagne, T. and Tano, K. (2016) Characterization of Waste from Attiéké Factory: Case of Azito Village (Abidjan, Côte d'Ivoire). European Scientific Journal, 12, 71-79.

http://www.ijsrp.org/research-paper-1217.php?rp=P727084

https://doi.org/10.19044/esj.2016.v12n35p73

[7] Kpata-Konan, N.E., Gnagne, T., Kouamé, Y.F., Konan, K.F., Kouamé, K.M. and Tano, K. (2018) Optimum Amount of Inoculum for Anaerobic Digestion of Cassava Waste. Livestock Research for Rural Development, 30, Article No. 60.

http://www.lrrd.org/lrrd30/4/kano30060.html

[8] Kpata-Konan, N.E., Kouamé, Y.F., Kouamé, K.M. and Konan, K.F. (2019) Characterization of Digestates from Anaerobic Co-Digestion of Manioc Effluent, Human Urine and Cow Dung. Journal of Water Resource and Protection, 11, 777-788. https://doi.org/10.4236/jwarp.2019.116047

[9] Ubalua, A.O. (2007) Cassava Wastes: Treatment Options and Value Addition Alternatives. African Journal of Biotechnology, 18, 2065-2073. https://doi.org/10.5897/AJB2007.000-2319

[10] Marache, L.E. (2001) Méthanisation des effluents et déchets organiques: État des connaissances sur le devenir pathogène. Thèse de doctorat, Ecole nationale vétérinaire de Toulouse (France), $183 \mathrm{p}$.

[11] Anonyme 1 (1981) Valorisation énergétique des résidus végétaux dans les pays du Conseil de l'Entente, fascicule No 1, Généralités. LBTP-APAVE, Abidjan, 257p.

[12] N'goran, K.D. (2006) Valorisation des ordures ménagères du district d'Abidjan: Production et caractérisation des paramètres physico-chimiques du biogaz. Mémoire de DEA, Université d'Abobo, Adjamé, 70 p.

[13] Kouamé, K.R. (2006) Valorisation de la bouse de vache des abattoirs de la ville d'Abidjan par production de biogaz. Mémoire de DEA, université d'Abobo, Adjamé, $51 \mathrm{p}$.

[14] Mahan, V. (2004) Etude de l'épuration des effluents issus des unités de production d'attiéké. Mémoire de DEA, Université d'Abobo, Adjamé, 38 p.

[15] Kpata, N.E. (2005) Comparaison de la biodigestion anaérobie des effluents issus de la fabrication d'attiéke fertilisé et non fertilisé à l'urine humaine. Pre-doctoral report, University of Abobo, Adjamé, $40 \mathrm{p}$.

[16] Kalloum, S., Bouabdessalem, H., Touzi, A., Iddou, A. and Ouali, M. S. (2011) Biogas Production from the Sludge of the Municipal Wastewater Treatment Plant of Adrar City (Southwest of Algeria). Biomass and Bioenergy, 35, 2554-2560. https://doi.org/10.1016/j.biombioe.2011.02.012

[17] Kpata-Konan, N.E., Gnagne, T., Konan, K.F., Kouamé, K.M., Kouamé, Y.F. and Tano, K. (2015) Biogas Production from Anaerobic Co-Digestion of Cassava Effluent and Human Urine. Pakistan Journal of Biotechnology, 12, 93-98.

[18] AFNOR (1994) Qualité de l'eau. Paris, 862 p. 
[19] Rodier, J. (1996) Analyse de l'eau: Eaux naturelles, eaux résiduaires, eau de mer. 8 ème édition, DUNOD, Paris, $1384 \mathrm{p}$.

[20] CEAEQ (1999) Détermination des solides dissous totaux et volatils dans les effluents: Méthode gravimétrique. Centre d'Expertise en Analyse Environnementale du, Québec, 9 p.

[21] Ricard, M.A., Drolet, V., Coulibaly, A., Laflamme, B.C., Charest, C., Forcier, F., Lachance, M.P., Pelletier, F., Levasseur, P., Pouliot, F., Godbout, S. and Lemay, S. (2010) Développer un cadre d'analyse et identifier l'intérêt technico-économique de produire du biogaz à la ferme dans un contexte québécois. Rapport final avril 2010, Centre de développement du porc du Québec Inc., Québec, 242 p.

[22] Doré, M. (1989) Chimie des oxydants et traitement des eaux. Tec et Doc, Lavoisier, Paris, $519 \mathrm{p}$.

[23] Maiga, A.H., Konate, Y., Wethe, J., Denyigba, K., Zoungrana, D. and Togola, L. (2008) Performances épuratoires d'une filière de trois bassins en série de lagunage à microphytes sous climat sahélien: Cas de la station de traitement des eaux usées de 21E (groupe EIERETSHER). Journal of Water Science, 21, 399-411. https://doi.org/10.7202/019163ar

[24] Barana, A.C. (2000) Avaliacao de tratamento de manipueira em biodigestores fase acidogenica e metanogenica. Botucatu, UNESP/FCA, Tese-Doutorado, 95 p.

[25] Liu, X., Liu, H., Chen, Y., Du, G. and Chen, J. (2008) Effects of Organic Matter and Initial Carbon-Nitrogen Ratio on the Bioconversion of Volatile Fatty Acids from Sewage Sludge. Journal of Chemical Technology and Biotechnology, 83, 1049-1055. https://doi.org/10.1002/jctb.1913

[26] Kouamé, Y.F., Yéo, M.T., Gnagne, T., Konan, K.F., N’Gouandi, K.F., Yapo, O.B., Séka, A. and Houénou, P.V. (2010) Stratégie d'élimination de l'azote des boues de vidange par Lit de Séchage à Ecoulement Non Saturé (LSENS). Journal de la Société Ouest-Africaine de Chimie, 29, 1-10.

[27] De La Farge, B. (1995) Le biogaz, procédés de fermentation méthanique. Edition Masson, Coll. Ingénierie de l'environnement, Paris, 233 p.

[28] Kalloum, S., Khelafi, M., Djaafri, M., Tahri, A. and Touzi, A. (2007) Etude de l'influence du $\mathrm{pH}$ sur la production du biogaz à partir des déchets ménagers. Revue des Energies Renouvelables, 10, 539-543.

[29] Igoud, S., Tou, I., Kehal, S., Mansouri, N. and Touzi, A. (2002) Première approche de la caractérisation du biogaz produit à partir des déjections bovines. Revue des Energies Renouvelables, 5, 123-128. 